\title{
Social Contracts: Pillars of Community Conservation Partnerships in Lore Lindu National Park, Indonesia
}

\author{
Ice Anugrahsari ${ }^{1,5}$, Mustofa Agung Sardjono², Nur Fitriyah³, Golar Golar ${ }^{4 *}$ \\ 1 Post Graduate Program of Forestry Faculty Mulawarman University, East Kalimantan, Indonesia \\ 2 Forestry Faculty of Mulawarman University, East Kalimantan, Indonesia \\ 3 Politics and Social Science Faculty of Mulawarman University, East Kalimantan, Indonesia \\ 4 Forestry Faculty of Tadulako University, Central Sulawesi, Indonesia \\ 5 Forestry Program of Agriculture Faculty Muhammadiyah University, Central Sulawesi, Indonesia \\ * Corresponding Author: Golar, Forestry Programme of Forestry Faculty Tadulako University, Palu, Central \\ Sulawesi, Indonesia Tel. +6281145210109. Email: golar_untad@yahoo.co.id
}

\begin{abstract}
The Community Conservation Partnership Agreement (KKM) was an effort to reduce, prevent and mitigate the impacts arising from the complexity of managing Lore Lindu National Park. Several approaches in building KKM in the National Park had been carried out by several parties but had not proceeded as expected. Social Contracts were built to advance community agreements. The purpose of this study was to explore the obstacles and strategies for implementing KKM in the National Park. A qualitative approach was used in this study, through in-depth interviews, field observations, and active research in the process of drafting the KKM agreement. The results showed there were multiple interpretations of the roles, functions, and work of the parties based on their authority and interests in building the KKM. This resulted in the KKM becoming unsustainable. Findings show that in order to re-establish the KKM requires strategic steps, which mediate across stakeholder interests. Partnerships towards effective social contracts would only succeed if there was recognition of, and meaningful involvement among parties that begin the design and planning processes and continue throughout the implementation phases of the partnership activities. The process of building a social contract must therefore begin with solid communication between stakeholders, which establish institutional mechanisms that are systematic, promote active coordinative, and are based on the trust and understanding between stakeholders.
\end{abstract}

Keywords: Conflict resolution; Natural resources; Co-management; Community Conservation Partnership; Lore Lindu National Park

\section{Introduction}

Lore-Lindu National Park (LLNP) was officially confirmed by the Minister of Forestry and Plantations in 1999. Previously, LLNP was designated by UNESCO in 1977 as a biosphere reserve. LLNP thus plays an important role in protecting ecosystems and biodiversity support systems, ranging for a diversity of flora and fauna from the Wallacea region, which includes various types of endemic species, as well as a high diversity of socio-cultural values.

As a national parks with a unique social culture, LLNP could not be separated from the challenges of land claims and forest encroachment. This issues hasa been problematic through the history of LLNP management. These conditions caused frequent social and tenure conflicts (Golar et al., 2019b) which resulted in the non-optimal management of LLNP (Golar et al., 2017; Irawan et al., 2016). The trigger factor for conflicts around forest areas in and around LLNP was the lack of clarity of policies designed by the government. Another aspect raised by Maesen and Cadman (2015) was the dilemma in forest conservation efforts relative to development indicators of local populations. Satyanarayana et al. (2012) added that unclear information about community rules, regulations and rights (see also Chankrajang, 2019) and the role of stakeholders in forest management also caused tensions and flared up as conflicts (Gupta and Koontz, 2019).

One community that experienced social conflicts over claims and land use was the Lembah Bada community (Golar et al., 2019b; Massiri et al., 2019). This community was unique as it was surrounded by forests that were still classified in a good condition. The Lembah Bada community 
settled in the LLNP area long before the area was designated a National Park. Interaction between the community and the forest had existed for a long time. Like other indigenous communities living among and near forests, the Lembah Bada Community has a reach tradition of local wisdom to preserve its forests (Golar et al., 2019a). These practices are considered multi-generational and adaptive, a heritage passed down from their ancestors.

Nevertheless, the park manager of LLNP still viewed the existence of the Lembah Bada community to be illegal, because they are considered to contradict regulations regarding the prohibition of land use in a National Park Area on pursuing its conservation goals. This led to tenurial conflicts between the community and LLNP management. Several efforts to resolve tenure conflicts had been carried out, both initiated by park management, local governments, and nongovernmental organizations. However, these efforts had not created acceptable terms among the stakeholders.

Meanwhile, on a national scale, several regulations were issued that could accommodate community participation in the management of conservation areas. Furthermore, the LLNP conducted a review of the zoning areas of the park to accommodate tenure concerns and engage in a conflict resolution process. The initiative was carried out to revitalize the Community Conservation Agreement (KKM), and one of those involved the communities from the Lembah Bada area. The KKM program was originally initiated by support from an influential international NGO: The Nature Conservancy (TNC), which worked in collaboration with several local NGOs in the 2000s. At that time, the KKM signing was facilitated to produce an agreement document, accompanied by a participatory management plan.

However, the implementation of KKM supported by TNC did not last long. After the project ended, several villages were considered to be in violation of the agreement, and until the time of writing, the program was unable to solve the problem of land use in the LLNP. The reason was that the mechanism for implementing the KKM program was inadequate due to a lack of commitment established between parties in ensuring the sustainability of the program (Wood et al., 2019). Based on this description, we pursued a study design to develop an in-depth study about the constraints of implementing the KKM program and potential strategies for creating social contracts to support the success of KKM and optimize conflict resolution efforts in the LLNP.

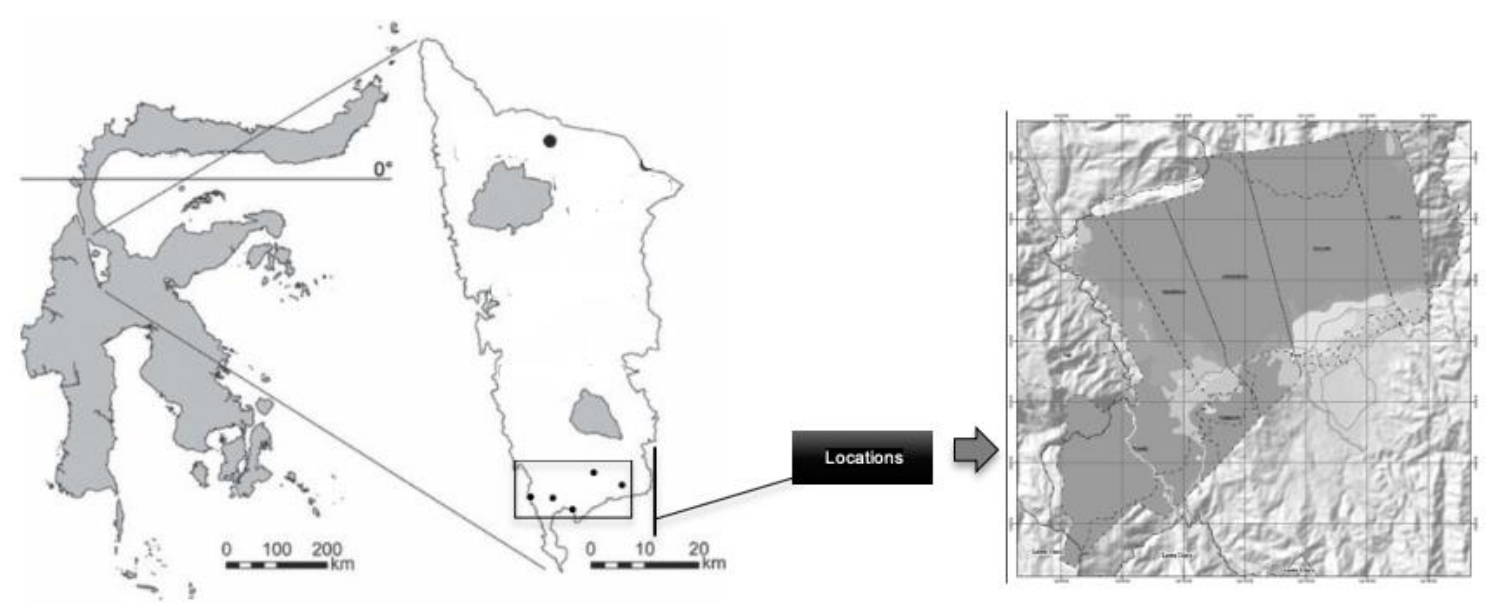

Figure 1. Research Locations at Lembah Bada in Lore Lindu National Park (Foto source: LLNP, 2020) 


\section{Materials and Methods}

\subsection{Study Area}

This research was carried out in Lembah Bada, a sub-district around the LLNP area of Central Sulawesi Province. Administratively, Lembah Bada consists of six villages, including Tuare, Lengkeka, Kageroa, Lelio, Tomihipi and Kolore (Figure 1). Most livelihoods of people in this region depend on the LLNP area, both in the form of land use within the Park boundaries and the collection of nontimber forest products.

\subsection{Data collection}

Data collection consisted of the following: Historical data collected about the management of national parks and the KKM program in the study area; direct engagement with communities living in and interacting with forest areas; examining the KKM formed by TNC; evaluating the KKM as part of broader revitalization interests in Lembah Bada; as well as considering the potential supporters of implementing social contracts and the identification of problems or obstacles in the application among counterparts. The data collection method was carried out through both involved observation and in-depth interviews, supported by thematic FGDs based on the research objectives.

Interviews were conducted with representative informants in each sample village, which were conducted purposively. There were five informants in each village. The main criteria used to select an informant includes: (a) the informant conducts land use activities within the forest area; (b) was a representative of the village community based on recommendations from community leaders or the local village head. Meanwhile, the thematic FGDs were carried out by inviting all informant representatives in each village, as well as validating the results of the in-depth interviews and observations that had been produced. To explore in-depth information related to field findings, indepth interviews were also conducted with six key informants, namely: two representatives of community leaders, two representatives of village heads, and two representatives of LLNP.

\subsection{Data Analysis}

Data were analyzed descriptively and qualitatively through a synthesis of empirical data obtained during interviews, field observations, and evaluating the process of drafting a KKM that was carried out in each of the sample villages. We began by analyzing the constraints of the KKM implementation supported by TNC. Thereafter we also analyzed the roles of the parties that carried out the process toward establishing a partnership agreement as a form of social contract in line with the broader objectives of our research.

Analysis of problems identified were conducted through the Fishbone approach of stakeholder analysis, which was used to identify the root of the problem, as well as the obstacles encountered in the partnership agreement the community and LLNP. Fishbone analysis was used to identify the various potential causes of an effect or a problem, and analyzed the problem through 6 categories, namely: Manpower (human resource input), Machine (infrastructure), Measurement (policy/regulation), Material (raw materials and natural resources), Money (financial), and motivation (encouragement and behavior) (Nolan, 2015). Through this analysis would be seen as the pattern of relationships and inhibiting factors causing the emergence of KKM problems in the LLNP.

Stakeholder analysis used the 4Rs (Right, Responsibility, Revenue, and Relationship) methods, related to the management of LLNP (Golar et al., 2019b; Islam et al., 2019). Through this analysis, the roles would be seen based on the 4 aspects (Rights, Responsibilities, benefits, and patterns of relations between stakeholders). 


\section{Results and Discussion}

\subsection{History of the KKM Program in LLNP}

Community interaction with LLNP had been ongoing for a long time beginning in the 1970s before the area was established as a national park. The establishment of LLNP took place through six stages: proposal (1967), statement decree (1982), appointment (1993), boundary arrangement (1995), confirmation (1997) and establishment as LLNP (1999). The main driving factor was the community's dependence on resources within the LLNP (Massiri et al., 2019). There were at least 76 villages directly adjacent to the LLNP. A mix of indigenous and migrants (Table 1) inhabit the villages. Indigenous inhabitants and migrants around LLNP live without conflict, and over tiem developed and respected cultural values, customs, norms and rules (Cuni-Sanchez et al., 2019; Handoko and Yumantoko, 2015; Hvenegaard et al., 2015) .

Table 1. Multi-ethnic distribution around the LLNP

\begin{tabular}{lll}
\hline No & \multicolumn{1}{c}{ Sub District } & Ethnicity \\
1 & Sigi Biromaru & Kaili \\
2 & Gumbasa & Kaili Ado, Edo \\
3 & Lindu & Kaili \\
4 & Kulawi & Kaili \\
5 & Kulawi Selatan & Kaili Moma \\
6 & Tanambulava & Kaili \\
7 & Palolo & Kaili \\
8 & Nokilalaki & Kaili Da'a \\
9 & Lore Utara & Pokerehua, Tawaelia-Baria \\
10 & Lore Piore & Behoa, Pokerehua \\
11 & Lore Tengah & Behoa \\
12 & Lore Barat & Bada \\
\hline
\end{tabular}

Sources: RPJP Document LLNP 2016-2022

In the course of its management, social dynamics occurred, mainly due to the migration of people around the LLNP. The main motivation for migration was on the need to meet family needs (Golar et al., 2019a; Satyanarayana et al., 2012). The phenomenon of migration began to appear in early 2017. Some of the triggering factors resulted in a decline in global economic conditions and the occurrence of conflict in Central Sulawesi (Poso city and surrounding areas), triggering a rush and exodus to other regions, especially to the LLNP. Since then, land clearing within the LLNP had begun in several locations.

This was the main impetus for launching the KKM program at LLNP. The program was initially initiated in 2002, through a TNC initiative. Although it was not an initial objective of TNC, the KKM grew out of an adaptation of the Central Sulawesi Area Integrated Development and Conservation Project (CSIDCP). This project sought to integrate conservation goals with regional development policies and programs. In the implementation of the KKM programs at that time, there were several problems however. On the one hand, there was a desire to meet the needs of the community, but on the other hand, there was a push to maintain the conservation status of the forest area. This phenomenon was also found elsewhere, which had an impact on widespread pressure on forest areas and the emergence of tenure conflicts (Riddell, 2013)

The history of land use in the LLNP area confirmed the longstanding interaction between the community and the forest area, long before LLNP was designated a Conservation Area. This information was the main consideration in the preparation of KKM in LLNP. According to some researchers, it was categorized as a form of recognition of their existence in conservation areas 
(Meehan et al., 2019; Zeb et al., 2019)

\subsection{Suboptimal KKM approach in LLNP}

The total area of LLNP covers 217,991 ha, located between Sigi and Poso Regencies. In other administrative terms, this means that LLNP directly interacts with 67 villages totaling 104,631 inhabitants. The conflict that occurred in Lembah Bada were closely related to people's lives in meeting their subsistence needs. The necessities of life of the community were very dependent on the results of farming in the LLNP area. On the other hand, the manager did not allow the community to enter, let alone inhabit the Forest Zone.

Several efforts to resolve social and tenure issues in the LLNP, including in Lembah Bada had been carried out. One of them was through the revitalization of KKM initiated by LLNP and its partners. However, in general, the KKM in the LLNP was generally not optimal due to the following reasons as described in the list below and in the fishbone diagram of Figure 2;

a. Human resources in Lembah Bada villages were relatively low and limited due to the lack of agricultural and forestry extension agents. Dominant factors were the low level of education and the lack of information, including outreach and interaction from the LLNP;

b. Infrastructure limitations due to areas/locations far from cities, low accessibility and limited information;

c. Policies and regulations that had not been well understood by citizens due to minimal outreach programs, including problems of coordination and authority among sectors that were still centralized and structural, as well as tenure issues and land claims that were never fully addressed;

d. Actual conditions in the LLNP that had not been fully executed, such as the absence of permanent boundaries, local institutions that were not involved enough, the limited management staff at LLNP, and growing community distrust of the LLNP;

e. Limited funding due to minimal or almost no financial institutions that reached villages and limited access to markets and information.

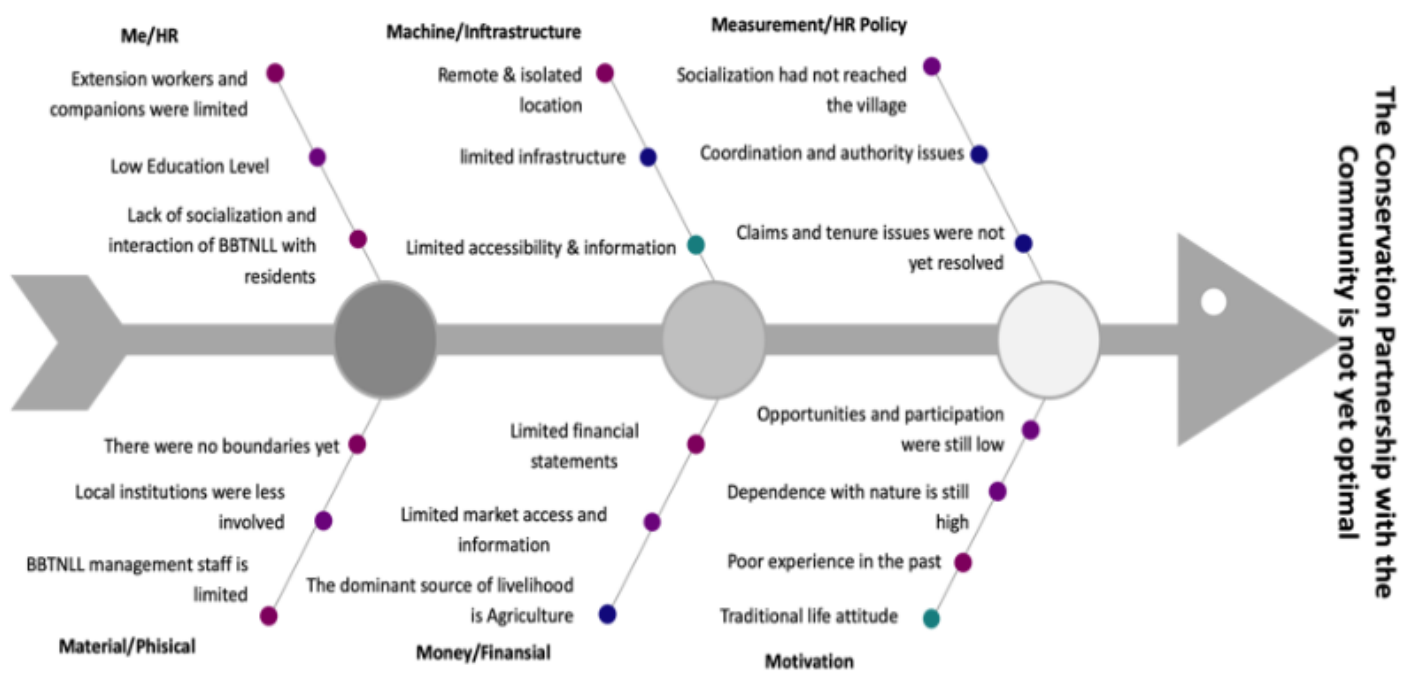

Problems Framework

Impact

Figure 2. Fishbone analysis of problems with the suboptimal KKM and LLNP

There were various collaborative activities within the partnership framework between LLNP 
and the Lembah Bada community. The activity was intended as a form of awareness and opportunity for LLNP to be able to interact with the community in and around LLNP. Forms of approach that had been carried out include the initiative to establish the boundaries of the LLNP area, Zoning Area Arrangement, Forest Police Volunteers (Pamswakarsa), Partnership Activities by LLNP Partner agencies (Table 2).

Table 2. Effectiveness of Prior Collaborative Approaches

\begin{tabular}{|c|c|c|c|c|c|}
\hline No & Approach & Short Description & $\begin{array}{l}\text { Achievements/ } \\
\text { Performance }\end{array}$ & Acting actor & Information \\
\hline 1. & $\begin{array}{l}\text { LLNP Area } \\
\text { Boundary Setting }\end{array}$ & $\begin{array}{l}\text { - Carried out } \\
\text { consultatively } \\
\text { since } 2006 \text {. } \\
\text { - The results of the } \\
\text { consultations were } \\
\text { outlined in the } \\
\text { proposed outer } \\
\text { boundaries and } \\
\text { LLNP zoning }\end{array}$ & 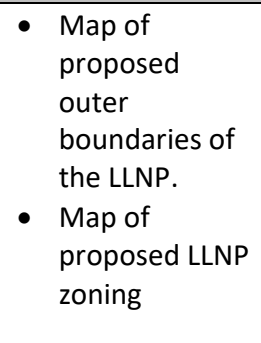 & $\begin{array}{l}\text { Balai Besar } \\
\text { LLNP } \\
\text { BPKH } \\
\text { Masyarakat }\end{array}$ & $\begin{array}{l}\text { - The parties were all } \\
\text { involved } \\
\text { - The consultative } \\
\text { process supported by } \\
\text { LLNP partners). }\end{array}$ \\
\hline 2. & LLNP Zoning & $\begin{array}{l}\text { - The activity was } \\
\text { intended to obtain } \\
\text { spatial planning in } \\
\text { the LLNP area in a } \\
\text { participatory } \\
\text { manner } \\
\text { - The activity began } \\
\text { with Participatory } \\
\text { Village Mapping } \\
\text { (PDP) with LLNP } \\
\text { partners }\end{array}$ & $\begin{array}{l}\text { - Village } \\
\text { participatory } \\
\text { mapping in the } \\
\text { form of the } \\
\text { community } \\
\text { version of land } \\
\text { classification } \\
\text { as a basis for } \\
\text { the } \\
\text { preparation of } \\
\text { LLNP zoning } \\
\text { - Zoning } \\
\text { recommendati } \\
\text { ons included } \\
\text { core zones, } \\
\text { traditional use } \\
\text { zones and } \\
\text { special zones }\end{array}$ & $\begin{array}{l}\text { - Balai Besar } \\
\text { LLNP } \\
\text { - LLNP } \\
\text { partners } \\
\text { - Society }\end{array}$ & $\begin{array}{l}\text { - Land classification } \\
\text { according to the } \\
\text { community: (a) } \\
\text { residential areas, (b) } \\
\text { agricultural land, (c) } \\
\text { pasture and cattle } \\
\text { grazing, (d) forest } \\
\text { areas (limited, daily } \\
\text { use, and customary } \\
\text { forest), (e) historic } \\
\text { sites/culture. }\end{array}$ \\
\hline 3. & Pam-Swakarsa & $\begin{array}{l}\text { - A program to } \\
\text { support BBLLNP in } \\
\text { the formation of } \\
\text { voluntary forest } \\
\text { security personnel } \\
\text { (Pam Swakarsa). }\end{array}$ & $\begin{array}{l}\text { Formation of } \\
\text { self-help } \\
\text { initiative for } \\
\text { the } \\
\text { management } \\
\text { of LLNP from } \\
\text { residents }\end{array}$ & $\begin{array}{l}\text { - Balai Besar } \\
\text { LLNP } \\
\text { - Society }\end{array}$ & $\begin{array}{l}\text { Membership of local } \\
\text { people recruited for } \\
\text { regular security and } \\
\text { monitoring/patrol } \\
\text { services in the LLNP } \\
\text { area. }\end{array}$ \\
\hline 4. & $\begin{array}{l}\text { Conservation } \\
\text { Collaboration }\end{array}$ & $\begin{array}{l}\text { - The partnership } \\
\text { process developed } \\
\text { by BB LLNP with } \\
\text { the involvement of } \\
\text { partners } \\
\text { - Done to } \\
\text { strengthen the } \\
\text { management of } \\
\text { LLNP that was } \\
\text { more } \\
\text { participatory, } \\
\text { equitable and } \\
\text { sustainable }\end{array}$ & $\begin{array}{l}\text { - Model } \\
\text { examples of } \\
\text { conservation } \\
\text { partnerships in } \\
\text { several activity } \\
\text { sites }\end{array}$ & $\begin{array}{l}\text { - } \text { BB LLNP } \\
\text { - } \text { LLNP } \\
\text { partners } \\
\text { (TNC, FP3, } \\
\text { EPAS) } \\
\text { - Society }\end{array}$ & $\begin{array}{l}\text { - Results were not } \\
\text { optimal }\end{array}$ \\
\hline
\end{tabular}




\subsection{Collaborative Program and the Role of Parties}

Collaborative management was a solution that was expected to solve the problems that had occurred since 2000 in the Bada Valley Lore Lindu National Park. The development of sustainability required adaptation in adjusting to existing policies and regulations. This was important in synergizing the perspective of the KKM as a pathway to establish the "Conservation partnership," which began with building a re-understanding between stakeholders involved in the management of LLNP (Golar et al., 2017; Gupta and Koontz, 2019)

The collaborative approach to the resolution of the Lembah Bada conflict began with a reflection activity to identify the fundamental problems, opportunities, and issues (Isoaho et al., 2019). The results of the reflection were then used as an important factor to consider the process of preparing a problem-solving plan (Sunam et al., 2015). Collaboration as conflict resolution in Lembah Bada was developed through the Vision of the Lore Lindu National Park Center, namely "Optimizing the Management of the Lore Lindu National Park to Create Sustainable Forests for the Fair Welfare of the People" and adapted to the fundamental problems that occurred in Lembah Bada. Through this vision, it was expected to become an alternative resolution approach for social and tenurial conflicts.

Different views and management goals were often seen as problems that could only be resolved if stakeholders had the same goals (Sahide et al., 2018). The identification and role of the parties were needed to identify their involvement and role in building a more solid and sustainable collaboration (Wittayapak and Baird, 2018). Identifying the roles of the parties included government stakeholders, local governments, the private sector, the community, and development partners (academics, donors, NGOs). Table 3 shows the roles and positions of the parties in the variant/window based on their involvement and influence on the management of LLNP.

Table 3. Group / Individual Stakeholder Mapping Window Based on Interests of Involvement and Its Impact on Management of LLNP Areas.

\begin{tabular}{|c|c|c|c|}
\hline \multirow{3}{*}{ INFLUENCES } & \multicolumn{3}{|c|}{ INTERESTS } \\
\hline & $\mathrm{HIGH}$ & $\begin{array}{l}\text { HIGH } \\
\text { - } \text { Governor and Regent (PEMDA) } \\
\text { - Ministry of Environment and Forestry (Dirjen } \\
\text { KSDAE) } \\
\text { - } \text { BBLLNP } \\
\text { - } \text { DPRD } \\
\text { - TNC, UNESCO } \\
\text { - NGOs }\end{array}$ & $\begin{array}{l}\text { LOW } \\
\text { - Religious and community leaders } \\
\text { - Teacher } \\
\text { - Village extension agents and } \\
\text { facilitators } \\
\text { - Press / Journalist } \\
\text { - Village government } \\
\text { - Related OPD in the Regency }\end{array}$ \\
\hline & LOW & $\begin{array}{l}\text { - Security forces } \\
\text { - Academic Institution (Untad) } \\
\text { - Environmental Services Users } \\
\text { - Farmer Group (Gapoktan) } \\
\text { - Timber or non-timber forest product collection } \\
\text { group }\end{array}$ & $\begin{array}{l}\text { - } \text { District Government } \\
\text { - } \text { BBNLL workers and staff and } \\
\text { partners } \\
\text { - Local Ethnic Society } \\
\text { - School Students and Students }\end{array}$ \\
\hline
\end{tabular}

In Table 3 there were 4 (four) variants or stakeholder windows, namely:

$\checkmark$ Window/variant (1) level of importance and involvement and influences were equally high,

$\checkmark$ Window/variant (2) stakeholders with high interests and involvement with low influences,

$\checkmark$ Window/variant (3) stakeholders with low interests and involvement, but had a high influences (authority), as well

$\checkmark$ Window/variant (4) stakeholders with low levels of interests and influence. 
Very high importance and influences presented a huge potential for identifying common ground for spearheading the Conservation Partnership. The main reason was that the community conservation agreement was a negotiation of community interests and the interests of preserving the functions of the LLNP area, so that if interests and influences become the main force, then the guarantee of success would be more likely (Bluffstone et al., 2018; Foundjem-Tita et al., 2018; García-López and Antinori, 2018; Sunam et al., 2015). Nevertheless, the main consideration must be related to the principle of regional clarity, user clarity, and clarity of resource use (Golar et al., 2017; Massiri et al., 2019). Another important aspect was the clarity of the constitutional rules regarding conservation partnerships, as pillars of guarantees for the formal foundation of the implementation of conservation partnership programs (Maesen and Cadman, 2015; Zeb et al., 2019).

\subsection{Sustainability Strategy Agreement for Community Partnerships Through Social Contracts}

Collaborative management was a solution that was expected to solve problems that had occurred since 2000 in the LLNP. Collaboration began with building an understanding between stakeholders involved in the management of LLNP. In this case the success of collaborative work could be achieved if the establishment of a shared view (common ground) between stakeholders, the recognition of each stakeholder and collective agreement on the LLNP management.

The KKM in Lembah Bada was one of the priorities for collaborative management in the LLNP. The KKM at this location was a strategic step to accommodate the local wisdom of the community (Bellon et al., 2020; Bluffstone et al., 2018), as well as minimizing the impact caused by encroachment around the LLNP. The participation and support of local/indigenous communities must be developed through social agreements in the form of social contracts that demonstrate the rights and obligations of each party.

Some of the steps needed in establishing a social contract for KKM in LLNP were described as follows:

a. Communicate and Consult Ideas; At this stage, LLNP and the parties who would be involved in the partnership process build agreements in the form of social contracts to first communicate ideas and plan activities to the community. Communities and stakeholders were aware of program plans, benefits, and potential impacts and risks. The parties involved were facilitators, donors and people/groups who during the process of building partnerships must be known and their track record was known by the community. At this stage of the process, representatives from people who were considered suitable to represent the community should be agreed upon in the process of discussion, negotiation; including being consulted and making decisions. Thus, the next phase had been obtained by people/groups anywhere in the community who had a voice and could be trusted to represent the community.

b. Develop Concept and Design Agreements; KKM ideas and ideas were carried out together openly and in a participatory manner with the community. The submission process began with identifying the actual location of the community's existing land use (gardens, rice fields, settlements, etc.). The results of the identification and mapping of the plantation location were then carried out by delineating land areas to obtain a rational and accommodative proposal area. Criteria for land that could be proposed included the following:

- Within the village administration boundary

- Located within the LLNP area

- Entered into the appropriate zoning of LLNP zoning

- Location priorities that had been managed by the village community

Based on these criteria, the results of the delineation were made into a collective proposal which then became the official proposal for the extent of the partnership area as accommodated in 
the Village Spatial Plan (RTRW Desa). This process was the process of land structuring and land use planning within the village administration area within the LLNP. These include:

a. Building Commitment and Institutional Management; The land compliance process in the form of a village spatial plan must ultimately obtain the consent of the citizens and be enacted in the form of village regulations (Perdes). Perdes that had shown the allocation of land for use, reserves and protection must have guarantees from the village government, where each member of the community receives rights to land, as well as guarantees the continued allocation of land designated for reserves and protection. In this case, it was necessary to have an institution from the community that would be responsible for the management of land and natural resources in the village.

b. Commodity Management and Commodity Development Activities: The community then discussed actions and relevant activities or actions needed to manage, maintain and protect natural resources, especially existing forests. In addition to the form of activities, the community was also invited to identify important and reliable commodity choices to support the community. Three types of commodities could be developed, namely: The actual commodity whose product was already in the village and currently the source of the community's actual livelihood; The potential commodities, namely the types of commodities whose products were in the village area, but the community had not yet developed them even though there was an available market potential; The prospective potential commodities, namely a type of commodity that does not exist in the village area, but could be produced and cultivated because the market was promising.

c. Welfare and Sustainability: At this stage, the community was invited to discuss the criteria and indicators for welfare and sustainability of partnership activities. This stage was important for establishing monitoring tools and gauging the level of success in implementing partnerships. Criteria indicators that had been compiled could be used as material for a shared vision in realizing partnerships to improve community welfare.

After all of these stages had been carried out, and subsequently obtained several approval and planning documents, it could be continued by arranging a collective agreement as a form of the social contract between the LLNP manager and the community. To be able to bind the commitments of all citizens, the agreement could be realized in the form of village regulations (Perdes) or joint agreements between villages in the LLNP area and LLNP managers.

\section{Conclusions}

There have been various collaborative approaches carried out by many parties since 2006, which include forms of KKM. These include participatory boundary arrangements, Zoning of the LLNP area, Pam-Swakarsa, and the collaborative co-management conservation areas. That these initiatives did not function optimally was due to the fact that programs were still approached in the conventional ways, in which community involvement was mobilized in unequal terms and dominated by LLNP managers. Furthermore, there was limited resources and access to information, involvement of local stakeholders was not maximal, the absence of finalized arrangements on boundaries, and past bad experiences in resolving tenure and social conflicts.

Conflict resolution models using partnership processes offer opportunities towards effective social contracts but which can only be carried out with the recognition, involvement, balance of decision making powers that are clearly laid out and agreed upon at the start of activities, and which last throughout the planning process, and continue in the implementation of partnership activities. Its clarity and respect for the rights and obligations of each party as well as clarity of benefits for the involvement and results of partnership activities are also essential. The availability of resources (time, energy, cost) and trust in the process must be built and implemented. This must also be rooted in a careful understanding of social issues of the community involved in the partnership 
process.

To strengthen social contracts in LLNP, the support of key stakeholders is very important. The main one was the Central Sulawesi Governor, playing a role in ensuring that social contracts run well by the development program in the Central Sulawesi region. The Lore Lindu National Park Office, which plays a role related to supervision, control and respect for the commitment to implementing partnerships include capacity building, empowerment and improvement of the welfare of the community around LLNP. One village head who had a role in promoting and ensuring social contracts were carried out by the agreement and village development plan. The community leaders played a role in disseminating the results of the agreement and together with citizens to implement the agreement well. Partners played a role in facilitating and assisting the implementation of the results of the agreement, especially in increasing the capacity and empowerment of local human and institutional resources.

Based the research results and conclusions of this research in closely examining KKM, the authors provide several suggestions for approaching overall collaborative management of conservation areas. There must be follow up for the initiatives that had been tried in the past through the principles listed herein. Furthermore, a serious assessment is needed about models to establish buffer zones that can work to the benefit of local communities while supporting the LLNP interests in conservation. LLNP managers must also be equipped with social engagement expertise and community sensitivity. Policies and regulations can also be strengthened and supported at the local (village) and district levels, which can help to provide quality assurance and certainty (including funding) through the APBDes in supporting collaborative management.

\section{Acknowledgments}

During this research, many parties were involved, both directly and indirectly. The authors would therefore like to thank to Haris Priyana who made the map, Akhmad Wijaya who provided guidance on data analysis, and reviewers who provided suggestions to improve this research, as well as Budi Setiawan who helped the manuscript editing, translating, and submission process.

\section{Authors' Contribution}

Mustofa Agung Sardjono, Nur Fitriyah, Golar who provided the conceptual models, theoretical support, data supports and advice in editing.

\section{Conflicts of interest}

The authors declare no conflict of interest.

\section{References}

Bellon, M.R., Kotu, B.H., Azzarri, C., Caracciolo, F. (2020). To diversify or not to diversify, that is the question. Pursuing agricultural development for smallholder farmers in marginal areas of Ghana. World Development 125, $104682 . \quad$ doi: https://doi.org/10.1016/j.worlddev.2019.104682

Bluffstone, R.A., Somanathan, E., Jha, P., Luintel, H., Bista, R., Toman, M., Paudel, N., Adhikari, B., (2018). Does Collective Action Sequester Carbon? Evidence from the Nepal Community Forestry Program. World Development 101, 133-141. doi. https://doi.org/10.1016/j.worlddev.2017.07.030

Chankrajang, T. (2019). State-community property-rights sharing in forests and its contributions to environmental outcomes: Evidence from Thailand's community forestry. Journal of Development Economics 138, 261-273.doi: https://doi.org/10.1016/j.jdeveco.2019.01.010

Cuni-Sanchez, A., Ngute, A.S.K., Sonké, B., Sainge, M.N., Burgess, N.D., Klein, J.A., Marchant, R. (2019). The importance of livelihood strategy and ethnicity in forest ecosystem services' perceptions by local communities in north-western Cameroon. Ecosystem Services 40, 
101000. doi: https://doi.org/10.1016/j.ecoser.2019.101000

Foundjem-Tita, D., Duguma, L.A., Speelman, S., Piabuo, S.M. (2018). Viability of community forests as social enterprises: A Cameroon case study. E\&S 23, art50. doi:https://doi.org/10.5751/ES-10651-230450

García-López, G., Antinori, C. (2018). Between Grassroots Collective Action and State Mandates: The Hybridity of Multi-Level Forest Associations in Mexico. Conservation and Society 16, 193. doi: https://doi.org/10.4103/cs.cs_16_115

Golar, Basir-Cyio, M., Rusydi, M., Bakri, R., Bohari, Pratama, M.F., Laihi, M.A.A. (2019a). Gold Mining and its Impact on Agricultural Land, Public Health, Violation of the Law: A Study on Poboya Traditional Mining, Palu, Indonesia. Ind. Jour. of Publ. Health Rese. \& Develop. 10, 924. doi: https://doi.org/10.5958/0976-5506.2019.02939.5

Golar, Mahfudz, Malik, A., Muis, H., Khairil, M., Ali, S.S.S., Razman, M.R., Awang, A. (2019b). The adaptive-collaborative as a strategy comunications for conflict resolution on the National Park 8.

Golar, Rachman, I., Umar, H., Alam, A., Labiro, E. (2017). The Poverty Assessment based on Subjective Criteria: Case Study of Rural Community near Protected Forest in Central Sulawesi. Australian Journal of Basic and Applied Sciences 9.

Gupta, D., Koontz, T.M. (2019). Working together? Synergies in government and NGO roles for community forestry in the Indian Himalayas. World Development 114, 326-340. doi: https://doi.org/10.1016/j.worlddev.2018.09.016

Handoko, C., Yumantoko, Y. (2015). LOCAL PERSPECTIVES ON TENURE RIGHTS AND CONFLICT IN FMU RINJANI BARAT, WEST NUSA TENGGARA PROVINCE. Jurnal Penelitian Kehutanan Wallacea 4, 157. doi: https://doi.org/10.18330/jwallacea.2015.vol4iss2pp157-170

Hvenegaard, G., Carr, S., Clark, K., Dunn, P. (2015). Promoting Sustainable Forest Management Among Stakeholders in the Prince Albert Model Forest, Canada. Conservation and Society 13, 51. doi: https://doi.org/10.4103/0972-4923.161222

Irawan, A., Mairi, K., Ekawati, S. (2016). Analysis Of Tenurial Conflict In Production Forest Management Unit (Pfmu) Model Poigar. Jurnal Wasian 3, 79. doi: https://doi.org/10.20886/jwas.v3i2.1595

Islam, K., Nath, T.K., Jashimuddin, M., Rahman, Md.F. (2019). Forest dependency, co-management and improvement of peoples' livelihood capital: Evidence from Chunati Wildlife Sanctuary, Bangladesh. Environmental Development 32, 100456. doi: https://doi.org/10.1016/j.envdev.2019.100456

Isoaho, K., Burgas, D., Janasik, N., Mönkkönen, M., Peura, M., Hukkinen, J.I. (2019). Changing forest stakeholders' perception of ecosystem services with linguistic nudging. Ecosystem Services 40, 101028. doi: https://doi.org/10.1016/j.ecoser.2019.101028

Maesen, L. van der, Cadman, T. (2015). Sustainable Forest Management: T he Role of Government Agencies, NGOs, and Local Communities in Western Australia. The International Journal of Social Quality 5. doi: https://doi.org/10.3167/IJSQ.2015.050204

Massiri, S.D., Nugroho, B., Kartodihardjo, H., Soekmadi, R. (2019). Institutional Sustainability of a Community Conservation Agreement in Lore Lindu National Park. Forest and Society 3(1), 64-76. doi: https://doi.org/10.24259/fs.v3i1.5204

Meehan, F., Tacconi, L., Budiningsih, K. (2019). Are national commitments to reducing emissions from forests effective? Lessons from Indonesia. Forest Policy and Economics 108, 101968. doi: https://doi.org/10.1016/j.forpol.2019.101968

Nolan, D.P. (2015). Specialized Reviews-CHAZOP, EHAZOP, Bow-Tie Analysis, Layers of Protection Analysis, Safety Integrity Level, Fishbone Diagram, and Cyber Security Vulnerability Analysis, in: Safety and Security Review for the Process Industries. Elsevier, pp. 17-27. doi: https://doi.org/10.1016/B978-0-323-32295-9.00005-7

Riddell, M. (2013). Assessing the Impacts of Conservation and Commercial Forestry on Livelihoods 
in Northern Republic of Congo. Conservat Soc 11, 199. doi: https://doi.org/10.4103/09724923.121002

Sahide, M.A.K., Fisher, M.R., Maryudi, A., Dhiaulhaq, A., Wulandari, C., Kim, Y.-S., Giessen, L. (2018). Deadlock opportunism in contesting conservation areas in Indonesia. Land Use Policy 77, 412-424. doi: https://doi.org/10.1016/j.landusepol.2018.05.020

Satyanarayana, B., Bhanderi, P., Debry, M., Maniatis, D. (2012). A Socio-Ecological Assessment Aiming at Improved Forest Resource Management and Sustainable Ecotourism Development in the Mangroves of Tanbi Wetland National Park, The Gambia, West Africa. AMBIO 41, 513-526. doi: https://doi.org/10.1007/s13280-012-0248-7

Sunam, R., Bishwokarma, D., Darjee, K. (2015). Conservation Policy Making in Nepal: Problematising the Politics of Civic Resistance. Conservation and Society 13, 179. doi: https://doi.org/10.4103/0972-4923.164201

Wittayapak, C., Baird, I.G. (2018). Communal land titling dilemmas in northern Thailand: From community forestry to beneficial yet risky and uncertain options. Land Use Policy 71, 320328. https://doi.org/10.1016/j.landusepol.2017.12.019

Zeb, A., Armstrong, G.W., Hamann, A. (2019). Forest conversion by the indigenous Kalasha of Pakistan: A household level analysis of socioeconomic drivers. Global Environmental Change 59, 102004. doi: https://doi.org/10.1016/j.gloenvcha.2019.102004 